\title{
The Joyful Experience in Learning Mathematics
}

\author{
Ricky S. Yabo \\ Department of Education Regional Office VII, Cebu City, Philippines \\ ricky.yabo@deped.gov.ph
}

\begin{abstract}
This study was conducted to determine the effectiveness of joyful scaffolds in teaching grade VIII mathematics in the Department of Education of the Philippines. Two intact groups were used as the subjects of the study. The experimental and control group were exposed to joyful and traditional scaffolds in teaching respectively. This study includes the pre-post assessments, significant improvements, and significant mean gain differences of students exposed to traditional and joyful scaffolds in teaching mathematics in terms of performance level. The findings of the study revealed that the joyful scaffold in teaching is more effective in improving the students' mathematics performance compared to the traditional scaffold in teaching and the skills acquired is sufficient enough to prove that these experimental group of students was able to gain experience from joyful approach and a positive change of attitude towards their view on mathematics was realized after the exposure. The cognitive progression was deepened, and attainment of knowledge was enhanced, psychomotor skills were activated and augmented through enjoyable mathematics learning activities, and students' interests and learning manners were maximized. Furthermore, the joyful scaffold in teaching in this study was immensely efficient in improving the students' mathematics performance compared to the traditional scaffold in teaching. Moreover, the outcome of this research supports the assertion that employing, relating, or incorporating several joyful media to learning boosted up students' academic performance especially those who are detached during the classroom discussion.
\end{abstract}

Keywords: joyful learning, enjoyable scaffolds, operational skills, mathematical vocabulary, comprehension.

\section{Introduction}

Mathematics is a systematic application of matter consequently makes our life in order and precludes anarchy (Anderssen, B., et. al., 2016). It is the foundation of all designs and inventions for without which the world cannot move even a little (Hodaňová \& Nocar, 2016). Some attributes that include ability of reasoning, creativity, hypothetical and critical thinking, ability in solving problem and even operative communication skills are fostered by mathematics (Kusmaryono, 2014). Everyone needs mathematics for the day-to-day life for existence hence to gain knowledge in mathematics is deemed necessary.

A distinctive mathematics teaching in the Philippines typically engages the question and answer nature of discussion. The mathematics secondary level curriculum in the Philippines which is currently being applied promotes using an array of teaching strategies among which are practical work, discussion, problem solving, investigations and practice and consolidation, as well as cooperative learning. The numeracy component of mathematical and problem solving skills focuses on competencies necessary for effective and efficient mathematical understanding and problem deciphering. Its emphasis is on how these mathematical skills would be applied to daily life situations. To this end, real-life examples 
are given for many of the experiences. During curriculum implementation, further emphasis will be necessary on contextualization of the mathematical competencies to align with different learning contexts, needs, and situational realities and practicalities of different learners (Department of Education of the Philippines, 2013).

Problems with learning and acquiring knowledge in mathematics are global and frequently subject to profoundly embedded views (Chinn, 2016). Most of the times during mathematics discussion students are sleepy, inattentive and disengaged henceforth teachers are also having challenges in making the subject more appealing and captivating. A balance is required between two most important things - knowing the type of learner and choosing a suitable teaching strategy.

Joyful learning is a type of learning procedure or occurrence which might create students feel gratification in a learning process (Udvari-Solner \& Kluth, 2017). Learning joyfully depicts a kind of emotion, articulating and causes great pleasure and a joyful insight is found to have constructive influence on the inspiration of learning (Kirikkaya, E. B., et. al., 2010). Joyful learning is an approach that entails a sense of pleasure, contentment, and comforting of the parties who are in the learning process. There is a bond of love and fondness between educators and learners and among learners and the learning manner will make each party seeking to give the finest to satisfy others (Wei, Hung, Lee, \& Chen, 2011). Learning joyfully in mathematics could make a big impact to the education of the students and makes knowledge and skills' assimilation meaningfully (Ariawan \& Pratiwi, 2017). Joyful learning activities are engaging and appealing (Minarni \& Napitupulu, 2017) such as mathematical games, puzzles, stories, activities relating numbers and quantities, recreational hand - on activities, realistic and life related problem solving that might help students learn holistically and develop a positive attitude, make connection with mathematics and everyday thinking, and make the mathematics classroom a place for recreation, fun, and enjoyable to stay.

\section{Methods}

\section{Research design}

The research methodology used in this study was essentially the quasi experimental method. Experimental and quasi-experimental research models assess whether there is an underlying relationship between independent and dependent variables. Plainly defined, the independent variable is the variable of influence and the dependent variable is the variable that is being influenced (Loewen \& Plonsky, 2015). Primarily, this method determined the efficiency of the use of joyful scaffolds in the hopes of finding effective means to teach grade VIII Mathematics. Specifically, this research intended to determine the pre-post assessments, significant improvements, and significant mean gain differences of students exposed to traditional and joyful scaffolds in teaching mathematics in terms of performance level among grade VIII junior high school students of Tungkop National High School, a public junior high school of the Department of Education of the Philippines, Region VII Cebu Province Division during the School Year 2018 - 2019. The control and experimental group were exposed to traditional and joyful scaffolds in teaching respectively. The traditional scaffolds cover the chalk talk, pasting of real objects on the board related to the topics presented and 
visual aids on a cartolina and manila paper while joyful scaffolds in teaching include learning activities that are engaging and amusing such as mathematical games, puzzles, manipulatives, stories, activities relating numbers and quantities, recreational hands-on activities, realistic and life related problem solving.

\section{Sample}

This study utilized 60 students which were purposively taken from the two sections in grade VIII level hence the Department of Education of the Philippines grade VIII level mathematics learning competencies (LCs) were also considered. The thirty (30) students in each group were selected through probability sampling specifically simple random sampling. In this sampling each student was chosen randomly and entirely by chance, such that each individual has the same probability of being chosen at any stage during the sampling process.

\section{Data collection}

This study utilized research instrument based and patterned to the standardized unit tests of the Department of Education to determine the pre-post assessments of students exposed to traditional and joyful scaffolds in teaching mathematics that were focused on the present condition to draw amplified insight into aspects which are functioning (Calmorin, 1994). There were four sets of unit test that includes LCs in illustrating and differentiating linear inequalities in two variables, graphing and solving problems involving linear inequalities in two variables, solving a system and problems involving systems of linear inequalities in two variables and illustrating a relation and a function and verifying if a given relation is a function. The groupings of the content areas are based on the mathematics curriculum guide of the Department of Education of the Philippines. Each unit test is equivalent to 25 points. There were true or false, multiple choices, and computations in every unit test. The tests contents were verified and validated by the certified and authorized Mathematics Master Teachers and Education Program Supervisors and presented and approved by the Schools Division Research Committee (SDRC) of the Department of Education Cebu Province Division, Regional Office VII, the Philippines. There were also words and observations being considered to express authenticity and attempts to describe students in natural situation (McDougall, 2015).

Moreover, the research instrument went through reliability test. Reliability was based from Calmorin (1994) in defining the uniformity of the research instrument testing the permanency of the response design of the respondents to be assured that the instrument is reliable, self-consistent, and unchanging. Pilot test was administered to 30 grade VIII students (not part of the research respondents). The assessment results were subjected to reliability alpha $\alpha$ test using the latest version of SPSS. An $\alpha$ of 0.70 and above are considered reliable. The results were all higher than 0.70 which further means that the response pattern of the respondents was dependable, consistent, and stable.

Both the control and experimental group were given a pre-test on grade VIII mathematics second quarter LCs before having been intervened by the independent variables which are the joyful and traditional scaffolds. They were also given a post-test on grade VIII mathematics second quarter LCs after having been exposed to the joyful and traditional scaffolds in teaching. 


\section{Data analysis procedure}

This study used a Z-test tool to determine the pre-post assessments of the students exposed to traditional and joyful scaffolds in teaching grade VIII mathematics in terms of performance level. This was utilized to find out whether the students had attained the $60 \%$ expectation level before and after the demeanour of the study. To find out if there is a significant improvement in the control and experimental group in terms of performance level, this study employed a T-test tool for related samples. Lastly, this study utilized a T-test of independent or uncorrelated means to determine if there is a significant mean gain difference in the two groups in terms of performance level.

\section{Results and Discussion}

This section illustrates the discussion, analysis, and interpretation of data on the tests' performance in mathematics of the two groups of grade VIII junior high school students as affected by the traditional and joyful scaffolds in teaching. The hypothetical mean was attained by using $60 \%$ as performance mark for the number of items on each learning competency. The critical $\mathrm{Z}$ and $t$-values are \pm 1.96 and 1.699 respectively at 0.05 level of significance.

Table 1

Summary of Test Results on Traditional Scaffolds in Teaching

\begin{tabular}{|c|c|c|c|c|}
\hline \multirow{2}{*}{ No } & \multirow{2}{*}{$\begin{array}{l}\text { Learning } \\
\text { Competency }\end{array}$} & \multirow[t]{2}{*}{ Stats } & \multicolumn{2}{|c|}{$\begin{array}{l}\text { Traditional Scaffolds in } \\
\text { Teaching }\end{array}$} \\
\hline & & & Pre-test & Post-test \\
\hline \multirow{3}{*}{1} & \multirow{3}{*}{ LC 1} & Means & 2.97 & 13.60 \\
\hline & & Std Dev & 0.76 & 5.83 \\
\hline & & Z-test Value & 86.70 & 1.32 \\
\hline \multirow{3}{*}{2} & \multirow{3}{*}{ LC 2} & Means & 4.03 & 11.23 \\
\hline & & Std Dev & 1.96 & 4.91 \\
\hline & & Z-test Value & 30.07 & 4.21 \\
\hline \multirow{3}{*}{3} & \multirow{3}{*}{ LC 3} & Means & 3.67 & 13.70 \\
\hline & & Std Dev & 1.21 & 3.28 \\
\hline & & Z-test Value & 51.29 & 2.17 \\
\hline \multirow{6}{*}{4} & \multirow{4}{*}{ LC 4} & Means & 6.57 & 15.53 \\
\hline & & Std Dev & 2.50 & 2.96 \\
\hline & & Z-test Value & 18.47 & 0.98 \\
\hline & & Means & 17.24 & 54.06 \\
\hline & \multirow{2}{*}{ Total } & Std Dev & 6.43 & 16.98 \\
\hline & & Z-test Value & 36.42 & 1.92 \\
\hline
\end{tabular}

Table 1 shows that the computed Z-test value during the pre-test is below and outside the non - rejection region thus the control group got a below average performance. This denotes that the students were not able to achieve the standard mark of the school. 
Furthermore, Table 1 revealed that students in the control group during the post-test got a calculated Z-test value higher than during the pre-test and it is within the non - rejection region. This means that their performance is categorized as average. The skills and techniques in patterns and algebra sink in a bit to the memory of the students. The result elucidated further that the grade VIII students exposed to traditional approaches in teaching progressively grasped on the skills and techniques in solving problems related to linear inequalities in two variables and function. Learning mathematics activities from informal sources happening in extra-curricular training or in out-of-study atmosphere have proven to be effective and able to motivate students to be taught (Hayes, 2007).

The preservation of the students' content knowledge on patterns and algebra affects a lot in their performance during the pre-test on the topics about linear inequalities in two variables and linear function. Hence, the pre-test assessment of the students before exposure to traditional approaches in teaching mathematics characterized as below average. Every subject in a particular class of disabilities has a different nature from that of the other class (Silver, 1997). Thus, each subject like Mathematics also needs different learning propositions. In carrying out the learning, the teacher absolutely needs a tool that can sustain its performance so that learning can take place with interesting and fun.

The aforementioned evaluation further demonstrates that students in control group during the pre-test lack of prior knowledge and techniques in solving problems related to patterns and algebra. Prior knowledge is the very rudimentary foundation in learning any topic. At their early age, students should be exposed to impending facets associated to mathematics to prepare them in the future (Shrestha, 2018). The basic concepts of elementary algebra should be inculcated in the mind of the students in their primary years. In this undemanding way, it will be easier for the students to grasp and link to an advanced learning related to patterns and algebra. The lack of the aforesaid realities caused the below average students' performance during the pre-test.

The abovementioned insinuations exemplified the effect of a usual intervention. Students' interest was motivated with the traditional approaches in teaching. With the use of traditional visual aids and teacher's intervention, students were encouraged to listen and do their best during the post-test.

Table 2

Summary of Test Results on Joyful Scaffolds in Teaching

\begin{tabular}{cclcc}
\hline \multirow{2}{*}{ No } & \multirow{2}{*}{$\begin{array}{c}\text { Learning } \\
\text { Competency }\end{array}$} & Stats & \multicolumn{2}{c}{$\begin{array}{c}\text { Joyful Scaffolds in } \\
\text { Teaching }\end{array}$} \\
\cline { 3 - 5 } & & Pre-test & Post-test \\
\hline \multirow{2}{*}{1} & \multirow{2}{*}{ LC 1 } & Means & 2.80 & 22.37 \\
& & Std Dev & 1.19 & 2.27 \\
& & Z-test Value & 56.15 & 17.78 \\
\multirow{2}{*}{2} & \multirow{2}{*}{ LC 2 } & Means & 3.03 & 18.90 \\
& & Std Dev & 1.13 & 2.98 \\
& & Z-test Value & 58.02 & 7.17
\end{tabular}




\begin{tabular}{ccccc}
\hline \multirow{2}{*}{ No } & \multirow{2}{*}{$\begin{array}{c}\text { Learning } \\
\text { Competency }\end{array}$} & Stats & \multicolumn{2}{c}{$\begin{array}{c}\text { Joyful Scaffolds in } \\
\text { Teaching }\end{array}$} \\
\cline { 3 - 5 } & & Pre-test & Post-test \\
\hline \multirow{3}{*}{3} & \multirow{2}{*}{ LC 3 } & Means & 3.37 & 20.67 \\
& & Std Dev & 1.45 & 2.29 \\
& & Z-test Value & 43.93 & 13.56 \\
4 & & Means & 7.17 & 20.27 \\
& \multirow{2}{*}{ LC 4 } & Std Dev & 3.11 & 2.56 \\
& & Z-test Value & 13.79 & 11.28 \\
& & Means & 16.37 & 82.21 \\
& \multirow{2}{*}{ Total } & Std Dev & 6.88 & 10.10 \\
& & Z-test Value & 34.73 & 12.04 \\
\hline
\end{tabular}

As presented in Table 2, the experimental group of students' assessments during the pre-test is below average since the computed Z-test value is outside and below the nonrejection region. They do not have yet the basic skill and technique in solving problems related to patterns and algebra. It denotes that an approach is a reaction to skills that come across in students' life. (Kundu \& Ghose, 2016). Basic skill narrows our logic of perceiving the world of mathematics, understands, and analyses the circumstances better as one would without proper knowledge. Absorbing the essential knowledge in mathematics gradually helps to grow the student's confidence level and may establish to be of some immense help during some significant events of students' lives. Educators should continue to converse to carry out new learning goals and instructional approaches that aim on safeguarding that our students progress with the skills essential to take part in our new global society (Gunter, 2007).

As displayed in Table 2, during the post-test, the experimental group of students attained an above average performance since the computed Z-test value is above and outside the non-rejection region. This assessment implies that the experimental group of students attained a performance which is above the standard goal of the school. The joyful approach and scaffold triggered and maximized the existing knowledge of the students on the topics about linear inequalities and function hence they were able to achieved ultimate goals of learning in the second quarter of elementary algebra. Booming methods for tapping student's prior knowledge need not be difficult. Vallori (2014) revealed that by merely soliciting students what they know about a topic before instruction can increase achievement. Mathematics instruction should construct on students' existing knowledge along with joyful and lively teaching techniques and strategies (Forman \& Steen, 2000). This is because students often enjoy applicable information that can support them in mastering new content.

Additionally, the abovementioned results show that the grade VIII students grasped already on the necessary skills needed in solving problems and exercises related to linear inequalities and function hence the post-test assessment of the students after exposure to joyful approaches in teaching elementary algebra is above average. 
Table 3

Improvements of the Control and Experimental Group

\begin{tabular}{|c|c|c|c|c|}
\hline No & $\begin{array}{c}\text { Learning } \\
\text { Competency }\end{array}$ & Stats & Control & Experimental \\
\hline \multirow{4}{*}{1} & \multirow{4}{*}{ LC 1} & $\begin{array}{l}\text { Pre-test } \\
\text { Mean }\end{array}$ & 2.97 & 2.80 \\
\hline & & $\begin{array}{l}\text { Post-test } \\
\text { Mean }\end{array}$ & 13.60 & 22.37 \\
\hline & & Mean Gain & 10.63 & 19.57 \\
\hline & & $t$-test Value & 4.78 & 5.43 \\
\hline \multirow{4}{*}{2} & \multirow{4}{*}{ LC 2} & $\begin{array}{l}\text { Pre-test } \\
\text { Mean }\end{array}$ & 4.03 & 3.03 \\
\hline & & $\begin{array}{l}\text { Post-test } \\
\text { Mean }\end{array}$ & 11.23 & 18.90 \\
\hline & & Mean Gain & 7.20 & 15.87 \\
\hline & & $t$-test Value & 4.57 & 5.37 \\
\hline \multirow{4}{*}{3} & \multirow{4}{*}{ LC 3} & $\begin{array}{l}\text { Pre-test } \\
\text { Mean }\end{array}$ & 3.67 & 3.37 \\
\hline & & $\begin{array}{l}\text { Post-test } \\
\text { Mean }\end{array}$ & 13.70 & 20.67 \\
\hline & & Mean Gain & 10.03 & 17.30 \\
\hline & & $t$-test Value & 5.14 & 5.40 \\
\hline \multirow{8}{*}{4} & \multirow{4}{*}{ LC 4} & $\begin{array}{l}\text { Pre-test } \\
\text { Mean }\end{array}$ & 6.57 & 7.17 \\
\hline & & $\begin{array}{l}\text { Post-test } \\
\text { Mean }\end{array}$ & 15.53 & 20.27 \\
\hline & & Mean Gain & 8.97 & 13.10 \\
\hline & & $t$-test Value & 5.06 & 5.20 \\
\hline & \multirow{4}{*}{ Total } & $\begin{array}{l}\text { Pre-test } \\
\text { Mean }\end{array}$ & 17.24 & 16.37 \\
\hline & & $\begin{array}{l}\text { Post-test } \\
\text { Mean }\end{array}$ & 54.06 & 82.21 \\
\hline & & Mean Gain & 36.83 & 65.84 \\
\hline & & $t$-test Value & 4.89 & 5.35 \\
\hline
\end{tabular}

Table 3 presents the students' improvement in mathematics after exposure to joyful and traditional approaches and scaffolds in teaching in terms of performance. Furthermore, Table 3 displays the computed $t$ - values attained by both groups in the competency which is the basis in denoting whether the students' improvement after exposure to joyful and traditional approaches in teaching mathematics in terms of performance is significant or not significant.

As shown in Table 3, the improvement between the control group's mathematics scores is significant. The post-test scores are higher than that in the pre-test. This means that 
the control groups' mathematics performance improved after the intervention and exposure to the traditional approaches in teaching. Accordingly, the null hypothesis of no improvement in the control group's performance in elementary algebra after exposure to traditional approaches is rejected. Thus, a significant increase in the students' performance in mathematics is observable.

These results denoted that the students have absorbed mathematics skills after exposure to the conventional technique in teaching, the lecture-discussion method. The approach significantly helped increase the student's performance in mathematics. This means that the mathematical learning process for grade VIII junior high school students that utilizes joyful approach takes place in a pleasant atmosphere and math specifically elementary algebra becomes easy. A satisfying and enjoyable learning discernment has an affirmative effect on students' learning motivation (Conklin, 2014).

On the other hand, the experimental group's post-test' performance is higher than that in the pre-test. The students' over-all mean gain provided way a significant increase in their performance. The computed $t$-test mean gain difference value is greater than the critical value. This result instigated to the rejection of the null hypothesis of no improvement in the experimental group's performance in Mathematics after exposure to joyful approaches and scaffolds. Thus, the students attained significantly better in the post-test than in the pre-test.

This result implies that joyful approaches in teaching have strengthened the performance of the students in experimental group. The teacher-made joyful presentations have motivated the students not to absent during mathematics classes. They were stimulated also with the effort shown by the teacher in preparing the lessons joyful and interesting.

The aforementioned results signify that the traditional and joyful approaches are effective in teaching mathematics. It is obvious as displayed in Table 3 that the abovementioned approaches in teaching increased the mathematics performance of the students in control and experimental group.

Table 4

Mean Gain Differences of the Control and Experimental Group

\begin{tabular}{|c|c|c|c|c|c|}
\hline No & $\begin{array}{c}\text { Learning } \\
\text { Competency }\end{array}$ & Stats & Control & Experimental & $\begin{array}{c}\text { Computed } \\
t \text { - Value }\end{array}$ \\
\hline \multirow{4}{*}{1} & \multirow{4}{*}{ LC 1} & Pre-test Mean & 2.97 & 2.80 & \multirow{4}{*}{7.49} \\
\hline & & Post-test Mean & 13.60 & 22.37 & \\
\hline & & Mean Gain & 10.63 & 19.57 & \\
\hline & & Std Dev & 6.03 & 2.53 & \\
\hline \multirow{4}{*}{2} & \multirow{4}{*}{ LC 2} & Pre-test Mean & 4.03 & 3.03 & \multirow{4}{*}{8.18} \\
\hline & & Post-test Mean & 11.23 & 18.90 & \\
\hline & & Mean Gain & 7.20 & 15.87 & \\
\hline & & Std Dev & 4.85 & 3.19 & \\
\hline \multirow{4}{*}{3} & \multirow{4}{*}{ LC 3} & Pre-test Mean & 3.67 & 3.37 & \\
\hline & & Post-test Mean & 13.70 & 20.67 & \multirow{3}{*}{8.22} \\
\hline & & Mean Gain & 10.03 & 17.30 & \\
\hline & & Std Dev & 3.74 & 3.08 & \\
\hline
\end{tabular}




\begin{tabular}{|c|c|c|c|c|c|}
\hline No & $\begin{array}{c}\text { Learning } \\
\text { Competency }\end{array}$ & Stats & Control & Experimental & $\begin{array}{c}\text { Computed } \\
t \text { - Value }\end{array}$ \\
\hline \multirow{8}{*}{4} & \multirow{4}{*}{ LC 4} & Pre-test Mean & 6.57 & 7.17 & \multirow{5}{*}{3.91} \\
\hline & & Post-test Mean & 15.53 & 20.27 & \\
\hline & & Mean Gain & 8.97 & 13.10 & \\
\hline & & Std Dev & 3.77 & 4.38 & \\
\hline & \multirow{4}{*}{ Total } & Pre-test Mean & 17.24 & 16.37 & \\
\hline & & Post-test Mean & 54.06 & 82.21 & \multirow{3}{*}{6.63} \\
\hline & & Mean Gain & 36.83 & 65.84 & \\
\hline & & Std Dev & 20.42 & 12.57 & \\
\hline
\end{tabular}

Table 4 presents the mean gain difference of the grade VIII junior high school students after exposure to traditional and joyful approaches in teaching mathematics. In totality, as shown in Table 4, the computed $t$-value is less than the tabled value and outside the non-rejection region at $\mathrm{p}=0.05$ level of significance. This elucidates that the mean gains between the two groups are significantly different. Hence, the hypothesis of no significant mean gain difference between the students exposed to joyful and those exposed to traditional approaches in teaching elementary algebra in terms of performance level is rejected. The joyful and traditional approaches in teaching elementary algebra specifically linear inequalities and functions significantly improved the academic performances of the students. Mathematics educators are anticipated to craft ideas to inspire students by joyful activities (Heywood, 2005) such as discerning, investigating, building, scheming, setting approach, and solving problems that are enfolded in mathematics games, puzzles, and hands-on activities. Instructional materials are those belongings that could make easy efficient teaching and enjoyable learning that is teaching aids through which learning progression may be promoted and aggravated under the classroom condition (Oyekan, 2000).

Activities crafted in mathematics teaching should intend to promote and prompt students to be involved and participate during the delivery of the lessons (Khan, 2012). Therefore, learning mathematics should be more fun and joyful both for students and teachers. It is a challenge of the mathematics teachers to think of innovations that would make the teaching of the lessons enjoyable for the students. Fun in mathematics learning is the delight of pleasure particularly in Math exercises and activities. Learning mathematics should be an enjoyable task to do, diverting the students' mind and body from any serious task or contributing an extra dimension to a joyful learning mathematics education. Learning mathematics should be connected with recreation and play, social functions, and even seemingly ordinary activities of daily living doable to articulate, more spontaneous, playful, or active event. Hence, the existence of the teaching aids in school does entail the imagination and creativity of teachers (Cunningham, 2015). 


\section{Conclusions}

The joyful scaffolds in teaching mathematics in this study has promoted better learning. The cognitive progressions were deepened and attainment of knowledge was enhanced, psychomotor skills were activated and augmented through enjoyable mathematics learning activities, and students' interests and learning manners were maximized. Furthermore, the joyful scaffold in teaching in this study was immensely efficient in improving the students' mathematics performance as compared to the traditional scaffold in teaching. The outcome of this research as reflected on the tables above supports the assertion that employing, relating, or incorporating several joyful media to learning may possibly boosted up students' academic performance especially those who were detached during the classroom discussion.

Further researches might be carried out using the same experimental design applied to a bigger group of respondents and to other subject areas. The results of this study can only apply to the teacher and students in the sample and cannot be considered as representative of a larger group of teachers or students in the Philippines due to sample limitations. However, the findings of this study may be beneficial to the future researchers who would probably be conducting a study on teaching technique related to this. This may serve as reference for those who would like to make further study.

\section{Recommendations}

Based and anchored on the findings of the study, educators may be perceptive in the learning styles of their students. They may be pliant enough in modifying their teaching approaches to suit to the need of the students. Teachers may clinch on the promising technologies that capture the concentration and interest of the students. They may go beyond from the traditional way of teaching and integrate technologies and other appealing and joyful activities that stir the mind of the students to learn. In this simple way, students congregate and scrutinize their own information as teachers guide them in the discovery of concepts. Teachers may be thoughtful in choosing the teaching method that is fitting to the interests and personality of the students and incorporate or employ joyful scaffolds in their mathematics classes. Mathematics teachers may craft and develop lesson plans that would stimulate students' desire to learn through joyful activities and exercises such as mathematics games, puzzles, hands-on activities, outdoor math activities, or any mathematics activity that would elicit the minds of the students to do discovering, exploring, creating, designing, setting some techniques, and solving math problems.

\section{Acknowledgements}

The researcher wishes to express his supreme appreciation and admiration to the following personalities who had helped him in the pursuit of this action research, for without them this self-effacing work would not be materialized.

Mr. Edison G. Dela Peña, Tungkop National High School Principal, for his kindness and sharing his superb insights for the fulfilment of this study;

Dr. Joel B. Umbay, Minglanilla 1 Public Schools District Supervisor, for his resonant wisdom and suggestions for the improvement of the schoolwork; 
Mr. Danilo A. Manguilimotan, Minglanilla 2 Public Schools District Supervisor, for his effort in looking into this humble and giving insight for the refinement of this study;

Dr. Pamela A. Rodemio, DepEd Cebu Province Division Education Program Supervisor for Mathematics, for sharing her expertise and precious insights and without her the improvement and finishing point of this work would not be possible;

Dr. Rhea Mar A. Angtud, former DepEd Cebu Province Schools Division Superintendent for granting her permission to the researcher to go on with this professional activity;

Dr. Marilyn S. Andales, DepEd Cebu Province Schools Division Superintendent, adviser of the Schools Division Research Committee, for her leadership and passion in managing the panel for the enhancement, development, and improvement of this study;

Dr. Leah B. Apao, Dr. Cartesa M. Perico, and Dr. Ester A. Futalan, DepEd Cebu Province Schools Division Superintendents, chairmen of the Schools Division Research Committee, for their headship and leading the members of the SDRC in reviewing and facilitating the approval of this undertaking;

Mr. Cesar A. Restauro Jr., DepEd Regional Office VII Education Program Supervisor for Mathematics, for his adeptness in sharing valuable views for the advancement of this endeavor;

Ms. Uki Rahmawati, SEAMEO Regional Centre for QITEP in Mathematics Facilitator, for her excellent and beneficial inputs during the conduct of the course on Joyful Learning in Mathematics Education that contributed to the enhancement of this study;

Dr. Wahyudi, SEAMEO Regional Centre for QITEP in Mathematics Director, for the opportunity and blessings bestowed on the researcher to acquire knowledge and proficiency of the concepts of joyful learning in mathematics education at SEAMEO Regional Centre for QITEP in Mathematicsin Yogyakarta, Indonesia that abetted to the successful implementation of the action research;

His Family, for their reassurances, unreserved love, prayers, support, and inspiration in fulfilling this study and professional venture;

Above all, to ALMIGHTY GOD, for HIS unconditional love, illumination, control, guidance and blessings, for without HIM this modest work would not be made possible; and

To those all who contributed to the research, his sincere thanks and appreciation.

\section{References}

Anderssen, B., Broadbridge, P., Fukumoto, Y., Kamiyama, N., Mizoguchi, Y., Polthier, K., \& Saeki, O. (2016). The Role and Importance of Mathematics in Innovation. New York, United States: Springer Publishing | ISBN 978-981-10-0962-4

Ariawan, V., \& Pratiwi, I. (2017). Implementing Joyful learning Strategy Using Treasure Clue Game Method in Order to Improve Reading Comprehension Skill. Journal Prima Edukasia, 5(2), 203-210. doi.org/10.21831/jpe.v5i2.11601

Calmorin, L. P. (1994). Educational Research Measurement and Evaluation (2nd ed., Vol. 293 p.: $23 \mathrm{~cm}$.). Mandaluyong City, Philippines: National Book Store, Inc. 
Chinn, S. (2016). Challenges in Teaching Mathematics: Perspectives from Students' Learning Difficulties. Journal of Numerical Cognition,2(1), 53-56. doi.org/10.5964/jnc.v2i1.26

Conklin, H. G. (2014). Toward More Joyful Learning. American Educational Research Journal, 51(6), 1227-1255. https://doi.org/10.3102/0002831214549451

Cunningham, C. (2015). Imagination: Active in Teaching and Learning (Master's Thesis ed.). Lincoln City, Nebraska: University of Nebraska. Retrieved from https://digitalcommons.unl.edu/teachlearnstudent/59/

Department of Education, Republic of the Philippines. (2013). K to 12 Basic Education Curriculum. Retrieved 2019, from https://www.deped.gov.ph/k-to-12/about/k-to-12basic-education-curriculum/

Forman, S.L., \& Steen, L. A. (2000). Making Authentic Mathematics Work for All Students (Vol. 24). In: Bessot A., Ridgway J. (eds) Education for Mathematics in the Workplace. Mathematics Education Library. Dordrecht, Netherlands: Springer, Dordrecht. doi.org/10.1007/0-306-47226-0_10

Gunter, G. (2007). Building student data literacy: An essential critical thinking skill for the 21st century. MultiMedia \& Internet@Schools, 14(3), 24-28. Retrieved from http://www.internetatschools.com/Articles/Editorial/Features/Building-Student-DataLiteracy-An-Essential-Critical-Thinking-Skill-for-the-21st-Century--59227.aspx

Hayes, D. (2007). Joyful Teaching and Learning in the Primary School. In Teaching Joyfully (pp. 1-9). Thousand Oaks, Canada: SAGE Publications. Retrieved from https://ru.b-ok2.org/book/887315/f84a9d

Heywood, P. (2005). Learning joyfully: An emotional and transformative experience. Melbourne Studies in Education, 46(1), 33-44. doi.org/10.1080/17508480509556414

Hodaňová, J., \& Nocar, D. (2016). Mathematics Importance in Our life. Proceedings of INTED2016 Conference, 7th - 9th March 2016, Valencia, Spain, 3086-3092. doi.org/10.21125/inted.2016.0172

Kundu, A., \& Ghose, A. (2016). Students' Attitude Towards Mathematics in Higher Secondary Schools of Southern Districts of West Bengal. Education India Journal: A Quarterly Refereed Journal of Dialogues on Education, 5(3), 159-180. Retrieved from

https://www.academia.edu/36810620/Students_Attitude_towards_Mathematics_in_Hi gher_Secondary_Schools_of_Southern_Districts_of_West_Bengal

Khan, S. B. (2012). Preparation of Effective Teachers of Mathematics for Effective Teaching of Mathematics. Journal of Educational and Instructional Studies in the World, 2(4), 82-88. Retrieved from https://www.researchgate.net/publication/236155384

Kirikkaya, E. B., Iseri , S., \& Vurkaya, G. (2010). A Board Game about Space and Solar System for Primary School Students. Turkish Online Journal of Educational Technology, 9(2), 1-13. Retrieved from https://eric.ed.gov/?id=EJ897997

Kusmaryono, I. (2014). The Importance of Mathematical Power in Mathematics Learning. International Conference on Mathematics, Science, and Education 2014 (ICMSE 2014), 35-40. Retrieved from https://www.researchgate.net/publication/303459705 
Loewen, S., \& Plonsky, L. (2015). An A-Z of Applied Linguistics Research Methods (1st ed. 2015 ed.). Springer.McDougall, J. (2015). The quest for authenticity: A study of an online discussion forum and the needs of adult learners. Australian Journal of Adult Learning, 55(1), 94-113. Retrieved from https://files.eric.ed.gov/fulltext/EJ1059160.pdf

Minarni, A., \& Napitupulu, E. E. (2017). Developing Instruction Materials Based on Joyful PBL to Improve Students Mathematical Representation Ability. Canadian Center of Science and Education, 10(9), 23-38. doi.org/10.5539/ies.v10n9p23

Oyekan, S. O. (2000). Foundations of Teacher Education. Ondo, Nigeria: Ebun-Ola Printers (Nig) Ltd.

Silver, E. (1997). Fostering creativity through instruction rich in mathematical problem solving and problem posing. Zentralblatt Für Didaktik Der Mathematik, 29(3), 75-80. https://doi.org/10.1007/s11858-997-0003-x

Shrestha, I. M. (2018). Roles of History and Philosophy of Mathematics in Mathematics Education. National Conference on History and Recent Trends of Mathematics (NCHRTM-2017), Balmeeki Campus, Kathmandu, Nepal, June 2-4, 2017, 1-7. Retrieved from https://www.researchgate.net/publication/328512406

Udvari-Solner, A., \& Kluth, P. (2017). Joyful Learning: Active and Collaborative Learning in Inclusive Classrooms (2nd ed.). 2455 Teller Road Thousand Oaks, California 91320: Corwin |A SAGE Publishing Company.

Vallori, A. B. (2014). Meaningful Learning in Practice. Journal of Education and Human Development, 3(4), 199-209. doi.org/10.15640/jehd.v3n4a18

Wei, C. W., Hung, I. C., Lee, L., \& Chen, N. S. (2011). Joyful Classroom Learning System with Robot Learning Companion for Children to Learn Mathematics Multiplication. The Turkish Online Journal of Educational Technology, 10(2), 11-23. https://www.researchgate.net/publication/239443461 
The Joyful Experience in Learning Mathematics 